\title{
Zircon U-Pb geochronology and geochemistry of Cambrian magmatism in the Coastal Block (Oued Rhebar volcanic complex, Moroccan Meseta): Implications for the geodynamic evolutionary model of North-Gondwana
}

\author{
A. El Attari ${ }^{\text {a }}$, M.F. Pereira ${ }^{\text {b,* }}$, H. Ezzouhairi ${ }^{a}$, M. El Houicha ${ }^{\text {a }}$, A. Jouhari ${ }^{\text {a }}$, I. Berrada ${ }^{\text {a }}$, A. Fekkak ${ }^{\text {a }}$, \\ N. Ennih ${ }^{\mathrm{a}}$, C.H. Hoepffner ${ }^{\mathrm{c}}$, C. Gama ${ }^{\mathrm{b}}$, J.B. Silva ${ }^{\mathrm{d}}$ \\ ${ }^{a}$ Chouaib Doukkali University Faculty of Sciences, Earth Sciences Department, BP.20, 2400, El Jadida, Morocco \\ ${ }^{\mathrm{b}}$ Instituto de Ciências da Terra, Departamento de Geociências, ECT, Universidade de Évora, Apt.94, 7002-554, Évora, Portugal \\ ${ }^{c}$ Faculty of Sciences, Mohammed V University, Rabat, Morocco \\ dinstituto Dom Luiz, Faculdade de Ciências da Universidade de Lisboa, Campo Grande, 1749-016, Lisboa, Portugal
}

\section{A R T I C L E I N F O}

Keywords:

U-Pb SHRIMP dating

Whole-rock geochemistry

Rift-related volcanism

Middle cambrian

Western meseta

North-gondwana

\begin{abstract}
A B S T R A C T
$\mathrm{U}-\mathrm{Pb}$ dating (SHRIMP) of magmatic zircons from an intermediate-mafic agglomerate of the Oued Rhebar Volcanic Complex (Coastal Block, Western Meseta) yielded a weighted mean age of $507 \pm 5 \mathrm{Ma}$. The obtained middle Cambrian age (Series 3, Stage 5) seems to be the best estimate for the crystallization of the ORVC volcanic rock, providing a maximum depositional age for the overlying Bouznika volcanosedimentary Formation. The ORVC rock is representative of middle Cambrian crust generation in North-Gondwana, but contains Ediacaran (ca. 546-542 Ma) and early Cambrian (ca. 536-526 Ma) inherited zircon which might be derived from recycling of older continental crust. This geochemistry study corroborates the existence of calcalkaline rhyolites, basaltic andesites and andesites in the ORVC rocks, but also of the existence, albeit to a lesser volume, of tholeiitic basalt. The relative higher volume of calc-alkaline compared to tholeiitic signature might reflect, in some extent, contamination of depleted mantle-derived magmas by the upper continental crust, as has been proposed for the origin of the same age rift-related igneous rocks from North-Gondwana, as the Iberian correlatives.
\end{abstract}

\section{Introduction}

In the Variscan orogenic belt, contrasted geodynamic settings have been proposed to comprehend the Late Ediacaran-Early Paleozoic evolution of North Gondwana (Pereira et al., 2006; Chelle-Michou et al., 2017; Álvaro et al., 2018 and reference therein; Arboit et al., 2019; Couzinié et al., 2019). A controversy persists regarding the geodynamic meaning of the geochemistry signature of the CambrianOrdovician magmatism that is characteristic of the Iberian (Sánchez García et al., 2008, 2010; Abati et al., 2010; Díez Fernández et al., 2015), Armorican (Pin and Marini, 1993) and Bohemian (Linnemann et al., 2007, 2014) massifs, in the Sardinia (Carmignani et al., 1994; Cocco and Funedda, 2019) and pre-Alpine basements (von Raumer et al., 2003), and to the east in Saudi Arabia and Iran (von Raumer et al., 2015). Actually, it is admitted that the Ediacaran magmatic activity was related to the development of a peri-North Gondwanan active margin (i.e. Avalonian-Cadomian magmatic arc system) which later gave rise to a Cambrian intra-continental rifting (Dalziel, 1997; Murphy and Nance, 2002; Nance et al., 2002; Torsvik, 2003). According to paleogeographical reconstructions, the subsequent long-lived extension of North-Gondwana which began in Cambrian times has culminated in the putative opening of Rheic Ocean during the Ordovician (Torsvik and Cocks, 2011; Stampfli et al., 2013). However, doubts remain as to whether the Avalonian-Cadomian magmatic arc extended until Cambrian times (Díez Fernández et al., 2019) and whether magmatic arcs may also have been formed during the Ordovician (Zurbriggen, 2015, 2017; Villaseca et al., 2016, Cocco and Funedda, 2019; Pereira et al., 2018 and references therein). In this way, we can admit that the late Neoproterozoic-early Paleozoic evolution of North-Gondwana may have been quite complex with the coexistence of regions dominated by intra-continental rifting that would be separated from other regions where magmatic arcs would develop.

In the Variscan orogenic belt of NW Africa the geodynamic meaning of the Ediacaran-Cambrian magmatism is still subject of debate (Pouclet

\footnotetext{
${ }^{*}$ Corresponding author.

E-mail address: mpereira@uevora.pt (M.F. Pereira).
} 